\title{
The Mitsui Collection
}

\author{
Simon James Bytheway \\ Nihon University
}

There are many reasons why historians, social scientists, and Japanologists would benefit from acquainting themselves with the Mitsui Collection. As an aspiring financial historian, I, for one, wanted to see what I could learn about Mitsui's role in the establishment of the early Meiji state. Mitsui is rumored to have borrowed heavily from the Tokugawa bakufu, or shogunate, to then on-lend to the rebellious forces of Chōshū and Satsuma,, presumably jostling to take the position as the new regime's premier merchant/bankers. Certainly, in the months and years that followed the "restoration" of the Meiji Emperor, petitions from the Japan's leading financial houses, namely Mitsui, Ono, and Shimada, were instrumental in driving Japan's new Minister of Finance, Inoue Kaoru, to introduce a national banking system based upon the American model. Having very close connections with the Mitsui house Inoue Kaoru gave Mitsui the great privilege of establishing Japan's first modern, Western-style bank, but insisted they work together with the Ono house. Threatened with the loss of government business, Mitsui and Ono jointly subscribed to then form the First National Bank in June 1873. On receipt of its charter, the First National Bank (a "predecessor" to the Mitsui Bank) was by far the most important bank for many years and was, in fact, the first joint-stock company to be formed in Japan. Naturally, the significance of Mitsui in Japanese banking, and their intrigues, hardly stops there. Just a few years later, for example, the Ono and other financial groups were suddenly bankrupted in mysterious circumstances by new legislation, leaving Mitsui pre-eminent in Japanese finance. So that was my personal starting point of interest, but there are surely many more reasons why researchers or scholars one might want to dip, or dig, into the Mitsui collection.

And what a collection it is, containing over 64,000 volumes of books and journals - 33,000 of which are Japanese imprints, with 11,000 works in Western languages, and 20,000 journals in Japanese and a variety of Western languages. Most of the Japanese language books were published in the years of Japan's long, post-war, economic boom (1952-1990), but a significant proportion of works (almost a fifth) date from before the end of World War II. The Japanese language books fall into wide variety of categories: economic history, economic theory, economic policy, international economics, money and finance, fiscal policy, industry, management, labor and social problems, statistical yearbooks, company and local histories, and biographies. In economic history alone, the collection contains over 2,187 volumes. A particular strength of the collection being the large number (some 2,276) of Japanese corporate histories (shashi) held: a testament to the centrality of Mitsui Bank's position in Japanese business and finance. Not unsurprisingly the English language books cover similar subjects, with a strong interest exhibited in biographies and corporate histories, but classic works on the history of countries other than Japan, especially Great Britain, Germany, Russia, and the United States, also abound. Finally, I might add that specialists, such as numismatists and diplomatic historians, are also likely to find invaluable works that are rare, and almost inaccessible outside Japan, in the present-day Mitsui collection. 
Which leads me to my last point: the Mitsui collection is highly accessible and ready to be used. Gifted by the Institute for Financial and Economic Research of the Mitsui Bank to the University of Pittsburgh (after its merger with the Sumitomo Banks in 1996) it immediately repositioned Pittsburgh University libraries as a leading repository of Japanese language materials, particularly in the fields such as corporate history. For many scholars around the world, it is geographically closer than Japan, and much easier to use and access. Moreover, financial assistance is in place to help researchers during their stay in Pittsburgh: named the Norio Tamaki Grant, in memory of the professor who found a new home for the collection in Pittsburgh. In many ways, the Mitsui collection exists now, open to all, as a testament to his foresight, the efforts of Richard Smethurst, Sachie Noguchi, Hiroyuki Good, and Rush Miller, and the extraordinary belief of the Mitsui Bank itself, that the entire collection of its Institute for Financial and Economic Research was best entrusted to an American university. Looking towards the future, I have no way of knowing what aspects of Japanese history are likely to draw scholarly interest, but I seriously recommend that committed researchers make good use of Pittsburgh University's Mitsui collection.

Editor's note: More information about the collection is available here:

http://www.library.pitt.edu/eal-mitsui-collect

\section{(c)) EY}

New articles in this journal are licensed under a Creative Commons Attribution 3.0 United States License.

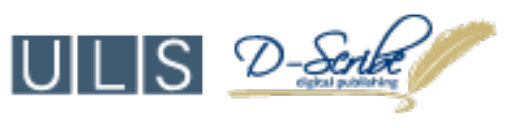

This journal is published by the University Library System, University of Pittsburgh as part of its D-Scribe Digital Publishing Program and is cosponsored by the University of Pittsburgh Press. 